\title{
Women and Nature: From Social Construction towards Environmental Protection
}

\author{
Case Study of Rembang Women Movement Rejects Mining Industry
}

\author{
Abdul Kodir \\ Department of Sociology \\ Universitas Negeri Malang \\ Semarang, Indonesia \\ abdul.kodir.fis@um.ac.id
}

Arif Prasetyo Wibowo

Civic Education Postgraduates

Universitas Pendidikan Indonesia

Bandung, Indonesia

arifprasetyowibowo08@gmail.com

\author{
Dia Puspitasari \\ Department of Sociology \\ Universitas Airlangga \\ Jalan Dharmawangsa Dalam, Indonesia \\ dia.puspitasari@gmail.com \\ Citra Dewi Kartika Paksi \\ Postgraduates of Management \\ Universitas Airlangga \\ Surabaya, Indonesia \\ citra.dewikp@gmail.com
}

\begin{abstract}
A fundamental understanding of human and natural relations occurs in Rembang, Central Java, Indonesia. This is related to environmental conditions and local communities, especially women who live on the slopes of the North Kendeng Mountains, Rembang. This study aims to explain how to distinguish women's knowledge of nature. In addition, this research aims to explain the human rights that are not only attached to themselves but also their right to the living space. This work used a qualitative research method. In addition, it used a critical paradigm and analysis of social construction theory and new social movements (NSM). The primary data in this study were obtained and collected directly from research subjects in the field. The observations were made by taking notes that occurred during the field study and focused to describe the phenomena observed by researchers. The results showed that the social construction of Rembang women of nature as 'Ibu Bumi' (Mother Earth) became the knowledge acquired by a theoretical process as explained by Berger. Through the processes of internalization, the externalization, and objectivation, 'Ibu Bumi' analogy is formed into a social construction. In addition, the Rembang's women movement is a representation of a new social movement (NSM) in which the movement's efforts focus on ecological issues where the Rembang women's movement is aimed at preserving the environment (Kendeng Mountains) from the threats made by the cement factory.
\end{abstract}

Keywords - women; nature; social construction; social movements

\section{INTRODUCTION}

The life of civil society in the context of developing countries is often represented with the problems of social welfare. The problems that occur in developing countries are often based on the development of the narrative welfare with an economistic concept which is in the form of economic growth. An economistic thought often creates areas which are considered as the granary poverty targeted by development projects [1]. Here is the argument why large-scale mining investments needed, which the existence of large enterprises to exploit the mine is part of a development project which also part of the poverty alleviation scheme. Almost in the history of mining in Indonesia, the behavior of state leaders or regional leaders always use the term about development to legalized the act. According to Bryant and Bailey, the state uses its political power to give privileged access to investors to exploit natural resources on the pretext can provide financial benefits through the tax [2].

An environmental issue in Rembang is important to be discussed on an in-depth scale. In the depth discuss area we can look at the exploitation of natural resources massively without seeing the objective conditions around. The establishment license of a cement factory given by the district government of Rembang to PT. Semen Indonesia is not considering the existence of citizens who depend on the region. Licensing mine will certainly undermine the determination of the mountains of North Kendeng and Watuputih Cekungan Air Tanah (CAT) or Groundwater Basin as in the conservation area.

Watuputih region is an area with a water recharge width of 2555.09681 Ha (calculation results via Geographic Information Systems). The region became the largest water infiltration that supplies springs that surround the area Watuputih. There are 109 springs in karst mountainous region Watuputih, estimates produced by springs in one day is as follows: The smallest springs $0.02 \mathrm{liter} / \mathrm{sec}$ in 1 day/24 hours/3600 minutes/86400 sec will produce 1728 liters of 
water in one day, most springs with debit of 600 liters/sec in one day will produce 51.84 million liters of water. Less than $10 \%$ of the discharge was used directly for the needs of the community and the rest is distributed to agricultural land. It indicates that the produced water from springs that exist around the karst region CAT Watuputih exceed the basic needs of society to water an average of 15-20 liters /day/person. If this value is evaluated as an economic potential, then the amount of water produced would exceed the value derived from the mining sector. Thus, the presence of mining activities has the potential to reduce or even eliminate the water supply and distribution to the springs that exist around the karst region CAT Watuputih [3].

Being aware of the environment being threatened by the presence of cement mining, the villagers make efforts of rejection. The resistance effect is not without reason; they have a strong reason to save the environment from the threat of cement mining [4]. What becomes interesting from residents rejection action against the exploitation of the cement plant is performed by the majority of mothers who work as a peasant. This is proof that women share common interests in maintaining the viability of nature. The women's movement in Rembang as a rejection action against the construction of a cement plant in an effort to save the environment is not the first time happening in the world.

\section{THEORETICAL}

\section{A. Social Construction (Berger and Luckmann, 1990)}

Berger and Luckmann in explaining social constructs aim to produce a basic conception of how individuals acquire the realities of knowledge and how society shapes the reality of knowledge [5]. Social reality consists of subjective reality, symbolic reality, and objective reality. Social construction explains the existence of dialectic between self and society. The dialectic takes place in a process with three "simultaneous moments", which are as follows:

1) Externalization is an adaptation to the sociocultural world as a product of the human world.

2) Objectification is a social interaction within the intersubjective world that is institutionalized or institutionalized.

3) Internalization is an individual identifying with the social institutions or social organization in which an individual belongs.

Social construction puts the premise on the idea that the everyday world has a subjective meaning for the individual [6,7]. The subjective world comes from thoughts and actions that are assumed to be real through the process of individual thinking about the action [8]. Berger and Luckmann state that humans construct a social reality, in which the subjective processes can be objectified. This process begins with the refraction of an action that allows the actors and other parties to notice that the action has regular and repetitive features [5]. Actors assume that there is reciprocity of type determination that will model their own behavior toward each other. This type of action will achieve reality status only if it is perceived by third parties.

Furthermore, Berger and Luckmann explain that humans are the creators of an objective social reality through the process of externalization as well as the objective reality of reaffecting humans through the process of internalization [5]. The dialectics between self and socio-culture takes place in a process with three simultaneous moments as described above externalization, objectification, and internalization. A thorough understanding of these three moments will result in an empirically adequate view of society [6].

\section{B. New Social Movements (NSM)}

New Social Movement (NSM) has developed since the mid-1960s [9]. NSM focuses more on nonmaterial goals and emphasizes changes in lifestyle and culture, such as movements that raise ecological, anti-war, feminist or earlyrising issues in the 1990s anti-globalization movement.

Rajendra Singh states that NSM has several characteristics such as [10]:

1) NSM put their ideological conception on the social space assumption of civil society has been eroded by the ability of state control. Therefore, NSM raises the issue of community and community self-defense against the growing expansion of the state apparatus.

2) NSMs generally involve grassroots politics, grassroots actions, often initiating micro-movements of small groups, aiming at local issues with a restricted institutional base. As such, the GSB generally responds to issues originated from civil society, they target the social domain of civil society, focusing on forms of communication and collective identity.

3) The structure of NSM is defined by the plurality of ideals, goals, desires, and orientations by the heterogeneity of the social basis. Referring to Touraine in the past, the capacity of a society to reproduce itself is limited. It is limited to the calculation of a social meta assurance of the social order, the laws of nature and the evolution of history. Forms of action and social movements become plural, across many paths, aspire to a variety of goals and voice various interests.

\section{METHOD}

This research used a qualitative research method with a critical paradigm. The use of a critical paradigm conducted by the researcher aimed to explain the fundamental contradictions related to development that threaten the deprivation of living space [11]. While the theoretical analysis in this study used social construction theory [5] and citizens' rights.

In determining the subjects of the study, a purposive sampling method was used. It means that the subjects of the research were selected based on the characteristics that have been determined. In addition, in the data collection, in-depth interviews, observation, and documentation were utilized. 


\section{RESUlTS AND DisCUSSION}

\section{A. Women's Rembang Knowledge of Nature}

Rembang women make an analogy of nature as 'Ibu Bumi' (Mother Earth). However, the conception of a man as a mother is different from earth as a mother. When humans as mothers, they will bear children, it is different from the earth as the mother who will give birth (produce) water, plants, and other crops. The results of what was born by the Mother Earth are the sources of life, not even for man but for all living things.

The internalization process that appears begins when the individuals identify themselves with the social institutions or social organization in which they belong to [6,7]. In the context of the Kendeng Range Rescue Movement conducted by Rembang's mothers, internalization occurs when Rembang's mothers identify themselves with JMPPK (Community Care Network for Kendeng Mountains) as the network that becomes an individual place member (Rembang's mothers). According to Berger and Luckmann, what happens in internalization is the process of accepting the definition of the institutional situation presented by others [5]. Individuals are ultimately not only able to understand the definition of others, but also together with others are able to establish definitions that lead to the formation of a common definition. At that time, the Rembang mothers in doing the internalization process to themselves also cannot be separated from what they experience in their daily activities. As farmers, they see the reality that nature is a source of livelihood for society.

Berger and Luckmann say that what has been internalized in him makes himself intrigued and experiencing a process in which humans absorb the world that is inhabited by his fellowmen, in this case, related to what is fought for his offspring and for the sake of nature [5]. Efforts to save nature by the Rembang mothers is based on the interests of children and grandchildren, in addition, environmental awareness is a manifestation of maintaining and conserve the earth. The struggle of Rembang women to reject the cement factory is based on the same reason that the Mother earth's analyzes must be preserved for the sake of the sustainability of posterity.

Human relations with nature that occurred in the mountains of Kendeng are closely related, even mutual relationships between humans and nature. Analyzing that the earth as the mother, explains that water as blood and bone as the soil and hair as the forest is also embedded in them so that the internalization experienced by Rembang mothers produce a philosophy of mother earth with the knowledge base as described above. In addition, they also make an analogy that the earth is like a human body where women have rights over their own bodies [12].

However, an internalization does not mean eliminating the world's objective position (that is, social institutions and institutional order as a whole) and making the individual's perception of power over social reality $[9,13]$. Internalization involves only the translation of objective reality into existing knowledge and persisting in individual consciousness, or translating objective reality into subjective reality.

In addition to the internalization process, the mothers also develop an externalization process. Externalization itself is an adaptation to the sociocultural world as a product of the human world [5]. The process of externalization is also done by making rejection efforts. The rejection effort made by Rembang mothers is a representation of the internalization process which is then internalized through an action in the form of rescue movement of mountains kendeng. The process of externalization that they do through various institutions, such as family institutions in which the understanding of the struggle that they did was given not only to her husband and child but relatives, social institutions (incorporated in JMPPK), and others.

Rembang mothers develop through various forums, especially the routine forums conducted by JMPPK and usually done alternately in their homes. The routine forum is done as an effort to awareness and understanding that what they are fighting is none other than for their children and for the sake of nature preservation. It is not only the discussion in the JMPPK forum but also how the development of the case of the cement factory that occurred. Of course, the consolidated results are also presented in the JMPPK forum to raise an awareness of the principle of openness among fellow Rescue fighters of Kendeng must be prioritized. The awareness that became the basis of the birth of the movement conducted by Rembang mothers also has a philosophy of struggle that motivates the movement of Rembang mothers.

Furthermore, the last process performed by developing mothers is objectification. The objectification of society puts the premise on the idea that the everyday world has a subjective meaning for the individual. The subjective world comes from thoughts and actions that are assumed to be real through the process of individual thinking about the action. Berger and Luckmaan suggest that humans construct a social reality in which subjective processes can be objectified [5]. In this context, this objectification process occurs when people are externalized by Rembang mothers and then the community conducts objectification.

The reality is that the objectification done by the community, especially the Rembang women post the internalization and externalization in various forms as described before, the segmentation of Rembang society categorized into two camps between the community who agree with the construction of cement factory with the community who do not agree with the construction of a cement factory.

This process begins with the refraction of an action that allows the actors and other parties to notice that the action has regular and repetitive features. It is when pro citizens with some arguments built that the impact on the environment will be minimized by cement factory (PT. Semen Indonesia) as it is in the latest EIA (environmental impact analysis) document. The actors assume that there will be a deterministic reciprocity 
that will model their own behavior toward each other. A behavioral model that implies this is an agreement that precisely with the presence of cement factory will bring positive impacts for the citizens of Rembang, for example, various CSR has been given to the people of Rembang.

A new objectivity can occur through the repeated affirmations given by others who share the same subjective definition. According to Berger and Luckmann, humans are the creators of objective social reality through the process of externalization as well as the objective reality affecting human return through the process of internalization [5]. The dialectics between self and socio-culture takes place in a process with three simultaneous moments as the described externalization, objectification and internalization above [5].

\section{B. Characteristics and Strategies of Rembang Women's Movement}

The environmental struggle movement carried out by Rembang women in rejecting the construction of a cement plant including a new social movement (NSM). This is in line with what Singh states that NSM emphasizes more on lifestyle and cultural changes such as movements that promote ecological issues such as those of Rembang women [10].

The environmental movement undertaken by Rembang women is one of their efforts to maintain their collective identity as peasants in which the women' families and successors depend from natural products. In addition, the basis of their struggle to save the Kendeng mountains from the construction of the cement plant, there is no element of coercion at all. What they do purely comes from awareness and intention to conserve the nature from destruction.

Rembang women's struggle in saving the mountains Kendeng is, ideologically, triggered by the expansion of the state through its apparatus. The cement company, which is a part of the country, will threaten to run the social space of women and the entire community in the mountains of Kendeng. Moreover, the state does not hesitate to make coercive and repressive efforts to women through the Rembang apparatus (military and police).

In addition, in an effort of rejection, women use two strategies, namely through eco-literacy and eco-design [14] in handling their ecological problems. Eco-literacy terminology can be defined as a way taken to foster ecological awareness in the community [14]. In the context of this research, ecoliteracy is manifested by women who develop Rembang extension process. Where through this process, is obtained from the awareness efforts undertaken women Rembang, about the importance of nature to those who still do not understand the ecological issues.

They do not only spread the awareness to their families but the people around them through informal and formal forums. Furthermore, in the realization of their action is the effort ecodesign.
Eco-design. is a continuation of the previous concept of Ekoliterasi. If eco-literacy performs an ecological recognition and awareness in general, then Eco-design becomes a concrete action mainly related to the context of industrialization [14].

Eco-design that was conducted by Rembang's women movements such as ritual petitioners, demonstrations at University of Gadjah Mada (UGM), attended the courts, a long-march as far as $122 \mathrm{KM}$, casting feet in front of the State Palace, and their symbolic resistance action by exploring the cultural value they have.

What the women are initiating and doing is a representation of their knowledge. Of course, nature-based knowledge and therefore their relation between human and natural tends to hold the concept of reciprocity. It is related to the awareness of women in their involvement in the movement of saving their environment.

\section{CONCLUSION}

The results of this study have contributed to explaining the formation of women's knowledge of nature through the process of social construction (internalization, externalization, and objectification). Rembang women associate nature as ' $I b u$ Bumi' (mother earth). They believe that the results of what is borne by the 'Mother Earth' is the source of life, not only for man but for all living things. Through this knowledge, they then formed a movement in an environmental conservation effort when threatened by the establishment of a cement plant.

Rembang women's movement is categorized as a new social movement (NSM) in which the movement focuses on ecological issues.

Whereas in the fight against the establishment of a cement plant, at least, they use two strategies namely eco-literacy and eco-design. Eco-literacy is an effort realizing the environmental awareness to family members or community conducted by Rembang's women. While eco-design is a real action undertaken by Rembang women. One of which is by casting their feet in front of the presidential palace for days.

\section{REFERENCES}

[1] Kodir, A., Mushoffa, I. Islam, Agrarian Struggle, and Natural Resources: The Exertion of Front Nahdliyin for Sovereignty of Natural Resources Struggle Towards Socio-Ecological Crisis in Indonesia, Karsa: Journal of Social and Islamic Culture, 25(1), 57-89. 2017.

[2] Bryant, R., Bailey, S, Third World Political Ecology, Taylor \& Francis. London. 2005.

[3] Ardianto, T.H, Dwicipta (eds). Rembang Melawan: Membongkar Fantasi Pertambangan Semen di Pegunungan Kendeng, Literasi Press. Yogyakarta. 2015.

[4] Soesilo, D., Kodir, A., Awalia, H.. Women's Leadership through the Context of Rembang Movement, International Conference on Contemporary Social and Political Affairs, 2(1), 3-8. 2016.

[5] Berger, P. L., Luckmann, T. Tafsir Sosial atas Kenyataan. Risalah tentang Sosiologi Pengetahuan, LP3ES. Jakarta. 1990.

[6] Dreher, J. The Social Construction of Power: Reflections Beyond Berger/Luckmann and Bourdieu. Cultural Sociology, 10(1), 53-68. 2016 . 
[7] Friedman, M.A. Perceptual Construction: Rereading The Social Construction of Reality Through the Sociology of the Senses. Cultural Sociology. 10(1), 77-92. 2016

[8] Vera, H. Rebuilding a Classic: The Social Construction of Reality at 50. Cultural Sociology. 10(1), 3-20. 2016.

[9] Wilde, Lawrence. Class analysis and the politics of new social movements. Capital and Class. 14(3), 55-78. 2010.

[10] Singh, Rajendra. 2010. Gerakan Sosial Baru. Yogyakarta: Resist Book
[11] Comstock, Donald E. "A Method for Critical Research", in Knowledge and Values in Social and Educational Research, ed. Eric Bredo dan Walter Feiberg. Philadelphia: Temple University Press. 1982.

[12] Soesilo, D., Kodir, A., Politik Tubuh Perempuan: Bumi, Kuasa, Perlawanan. Jurnal Politik, 1(2), 317-330. 2016.

[13] Lynch, T. Social construction and social critique: Haslanger, race, and the study of religion. Critical Research on Religion, 5(3), 284-301. 2017.

[14] Capra, Fritjof. Titik Balik Peradaban. Yogyakarta: Bentang. 2004. 